\title{
GEOLOGICAL RECONNAISSANCE IN THE CALEDONIAN FORELAND OF EASTERN NORTH GREENLAND WITH COMMENTS ON THE CENTRUM LIMESTONE
}

\author{
John S. Peel
}

During the latter half of the 1979 field season, geological reconnaissance was undertaken in eastern North Greenland (fig. 30), in the foreland to the Caledonian mountain chain, as a preliminary to mapping programmes planned for 1980 . The principal aim of the reconnaissance was to study a cross-section from Danmark Fjord to Romer Sø (fig. 30) in Kronprins Christian Land and to establish a local stratigraphy suitable for map compilation. In addition, the northern part of Valdemar Glückstadt Land (fig. 30) was visited to investigate reports of Ordovician and Silurian strata in an area which preliminary mapping during 1978 had indicated as earliest Cambrian and Precambrian.

In northern Kronprins Christian Land it proved possible to recognise, within the so-called Centrum Limestone of Adams \& Cowie (1953), the complete sequence of Ordovician-Silurian carbonate formations described by Christie \& Peel (1977) from southern Peary Land to the north-west, namely, in ascending order, Wandel Valley Formation, Børglum River Formation, un-named Silurian (?) dolomite formation and un-named Silurian limestone formation. Carbonate mounds are also present, as are the overlying shale and flysch formations known from Peary Land. The transect from Danmark Fjord to Romer Sø revealed frequent repetition of individual carbonate units due to thrusting and high angle reverse faulting.

In northern Valdemar Glückstadt Land a similar sequence, from the Wandel Valley Formation to the un-named Silurian flysch formation, was found to overlie the Kap Holbæk Formation.

\section{Valdemar Glückstadt Land}

Restricted field work during 1978 in the northern part of Valdemar Glückstadt Land had suggested that much of this part of the peninsula was composed of the Portfjeld Formation, now known to be of Early Cambrian age (Peel, 1980), and the Fyns Sø Formation of probable late Proterozoic age (O'Connor, 1979; see map to accompany Rapp. Grønlands geol. Unders 88, 1979).

However, a cephalopod collected in situ by Eigil Knuth on 2nd June 1950 at Kap Ludovika (fig. 30, KL) and identified by myself during 1974 as Armenoceras cf. A. arcticum Troedsson, 1926, clearly suggesed that strata of Middle-Late Ordovician age occurred at the north-west corner of the peninsula. Such strata would be equivalent to the Børglum River Formation of Peary Land (Troelsen, 1949; Christie \& Peel, 1977). In addition, significant records of post-Cambrian Lower Palaeozoic faunas were made by geologists of Greenarctic Consortium engaged in petroleum geology exploration, during 1971, along the north-eastern shore of Valdemar Glückstadt Land. Dawes (1976) indicated a Cambrian to Silurian sequence in the area. 


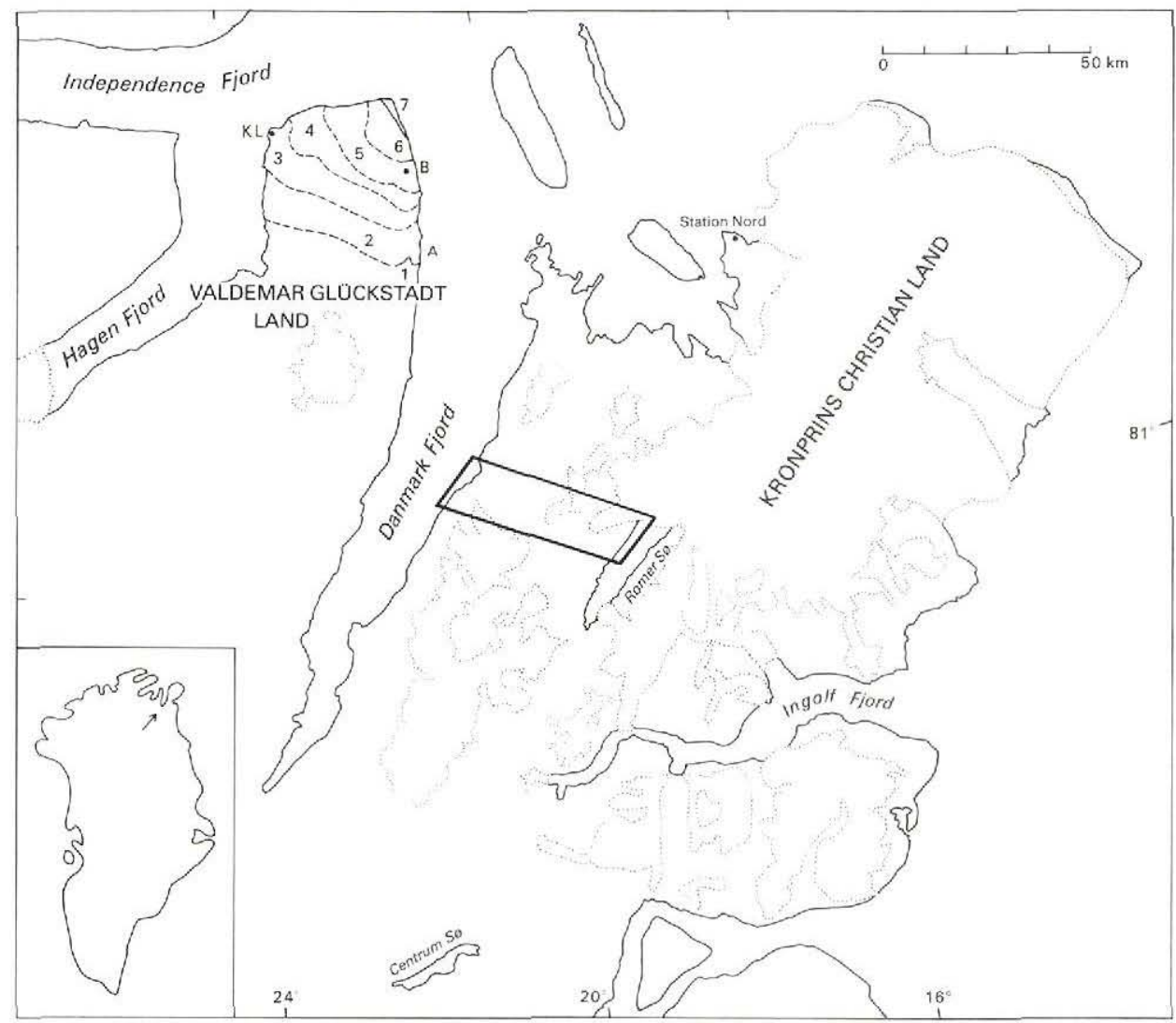

Fig. 30. Locality map, north-eastern Greenland. Geological formations in northern Valdemar Glückstadt Land are indicated schematically. 1, Kap Holbæk Formation; 2, Wandel Valley Formation; 3, Børglum River Formation; 4, un-named Silurian (?) dolomite formation; 5, un-named Silurian limestone formation, including a carbonate mound at locality B; 6, un-named Silurian black shale and flysch formations; 7, Wandel Sea Basin deposits. The quadrangle locates fig. 32. A, B, KL are localities discussed in the text.

Exposure of bed rock is poor throughout much of northern Valdemar Glückstadt Land, with the exception of the eastern shore. However, field work during 1979, based primarily on helicopter reconnaissance, demonstrated the presence of all the Ordovician to Silurian formations previously recorded by Christie \& Peel (1977) from southern Peary Land. A schematic geological map is included in fig. 30 .

The oldest strata examined were sandstones exposed in the northward flowing river at locality A (fig. 30). Here, about $15 \mathrm{~m}$ of bioturbated, laminated to thin bedded, locally cross-bedded, buff to grey, medium-grained glauconitic sandstone with greenish silty intercalations are overlain by $5-8 \mathrm{~m}$ of pale buff to grey, generally thin bedded cherty dolomite (fig. 31). The dolomites are sporadically cross-bedded and contain pockets of intraformational conglomerate. Overlying limestones and dolomitic limestones are dark weathering, massive to thick bedded with a crude nodular lamination and stringers of intraformational 
Fig. 31. Dolomites of the Wandel Valley Formation (WV) overlying sandstones of the Kap Holbæk Formation $(\mathrm{KH})$ at locality A, Valdemar Glückstadt Land. The cliff, viewed from the southwest, is about $50 \mathrm{~m}$ high.

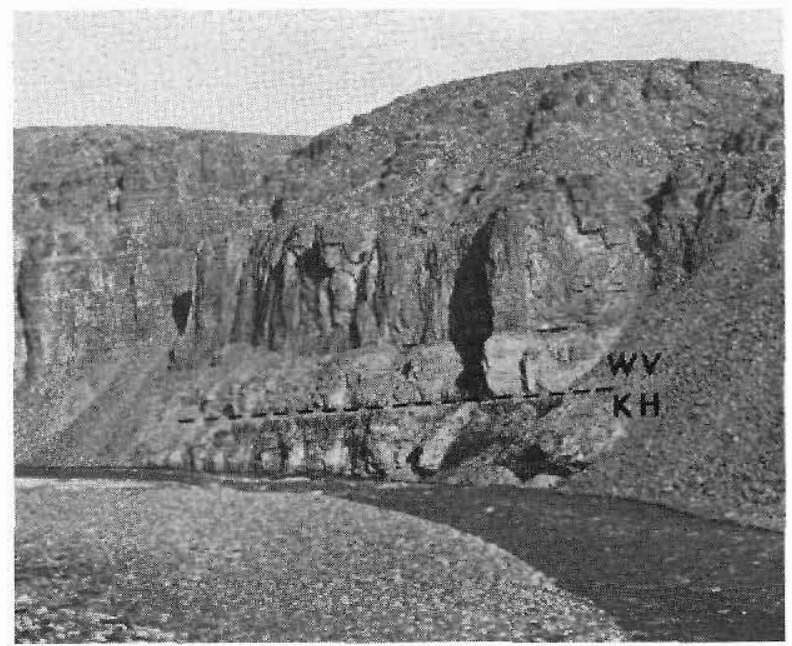

conglomerate. Higher in the sequence, the dark limestones become thinner bedded, paler grey and more dolomitic.

The greenish weathering bioturbated sandstones are correlated with the Kap Holbæk Formation of Adams \& Cowie (1953) of Early Cambrian age. Approximately equivalent sandstones and associated shales in southern Peary Land are referred to the Buen Formation (Christie \& Peel, 1977). The overlying pale dolomites and succeeding darker dolomitic limestones are assigned to the Wandel Valley Formation of Early-Middle Ordovician age. The formation, which is locally richly fossiliferous in its lower part, is well exposed over a distance of about $6 \mathrm{~km}$ in the gorge downstream to the north of locality A, dipping about $4^{\circ}$ to the north.

The unconformity between the Kap Holbæk Formation and the Wandel Valley Formation was not discernible in individual outcrops. However, the extent of this regional overstep by the Wandel Valley Formation, noted previously by Peel (1979), is evident from the absence of the Brønlund Fjord Group and Tavsens Iskappe Group of Early to Late Cambrian age. These units are approximately $1000 \mathrm{~m}$ thick in western Peary Land where the Wandel Valley Formation rests on strata of Late, possibly latest, Cambrian age (Peel, 1979; Ineson \& Peel, this report).

The contact between the Wandel Valley Formation and the overlying Børglum River Formation was not observed. However, tors composed of this latter unit occur on dark weathering hills to the north of locality A. At Kap Ludovika (KL in fig. 30) about $70 \mathrm{~m}$ of typical Børglum River Formation are well exposed and yielded a fauna including Receptaculites, Maclurites and Calapoecia.

The un-named Silurian (?) dolomite formation of Christie \& Peel (1977), now known to be of Ordovician and Silurian age, forms low hills in north-western Valdemar Glückstadt Land which show the characteristic stripey alternation of pale dolomites and darker limestones or limey dolomites yielding thin-shelled pentamerid brachiopods. Outcrops have not been observed near the eastern shore, although the formation is presumed to occur in this area when account is taken of the regional dip. Large scale faulting has not been observed within the northern part of the peninsula but its presence can not be excluded. 
The un-named Silurian limestone formation of Christie \& Peel (1977) can be seen in stream sections near the north coast of Valdemar Glückstadt Land and as tors on hills near the eastern coast. Sections of more than a few metres are apparently rare. Carbonate mounds are also present. At locality B (fig. 30) black shales with graptolites of the un-named Silurian black shale formation rest on the flank of such a mound. A few kilometres to the north, sandstones and siltstones of the un-named Silurian flysch formation appear to have overstepped the shale onto the mound in similar fashion to reports from Peary Land by Christie \& Peel (1977) and Lane \& Thomas (1979).

At the north-east corner of Valdemar Glückstadt Land some tens of metres of buff coloured, cross-bedded sandstones are well exposed in stream sections and along the coast. Haller $(1970,1971)$ suggested that the outcrop was composed of Carboniferous to Lower Permian sediments. In the geological map accompanying Rapp. Grønlands geol. Unders. 88 (1979), the sediments are referred, without discussion, to the Ladegårdsåen Formation of Håkansson (1979) of Late Jurassic - Early Cretaceous age. Geologists of Greenarctic Consortium visited the locality in 1972 and suggested that the unconsolidated sands were possibly Tertiary deposits unconformably overlying the immediately adjacent Lower Palaeozoic.

\section{Kromprins Christian Land}

General interpretations of the geology of northern Kronprins Christian Land are given by Haller $(1970,1971)$ and Dawes (1976). In terms of the structural model employed by Haller (1971, fig. 88), most of the area between Danmark Fjord and Romer Sø visited during 1979 lies within the foreland to the Caledonian mountain chain which runs south-north along much of Greenland's east coast. However, the easternmost part of the visited area, just north-west of Romer Sø, was assigned by Haller to a zone of nappes. The interface between this zone and the foreland was considered to trend approximately north-east in the direction of Station Nord (fig. 30).

A base for Haller's structural analysis was provided by Fränkl $(1954,1955)$ who briefly visited the area south and south-east of Romer Sø during 1952 and 1953. Field observations concerning Precambrian to Silurian sedimentary rocks around the head of Danmark Fjord and south-east toward Centrum Sø were made by Adams \& Cowie (1953). Additions and modifications to this stratigraphy have been proposed by Fränkl (1954, 1955), Cowie (1961, 1971), Lane (1972), Scrutton (1975), Clemmensen (1979) and Collinson (1979, see also this report). Geologists of Greenarctic Consortium visited northern Kronprins Christian Land during 1969-72; some of their results were summarised by Dawes (1976).

\section{Stratigraphy}

As noted by Fränkl (1954, 1955) and Haller (1971), most of the area visited during 1979 is composed of Lower Palaeozoic strata. These are principally carbonates and were given the name Centrum Limestone by Adams \& Cowie (1953) in the area between the head of Danmark Fjord and Centrum Sø (fig. 30). Silurian clastic sediments of the Profilfjeldet Formation (Fränkl, 1955) occur above the carbonates while probable Proterozoic clastic sediments, here referred to informally as sandstones 1 and 2, were mapped in the south-east (fig. 32). 


\section{The Centrum Limestone problem}

The Centrum Limestone has an involved nomenclative history, with significant modifications in its definition since its description by Adams \& Cowie (1953). It is now recognised that this embracive term in its original definition includes, at least in northern Kronprins Christian Land, the entire Ordovician and Silurian carbonate sequence described from southern Peary Land by Troelsen (1949) and Christie \& Peel (1977). The issue is complicated by the subsequent naming of several units within the Centrum Limestone (fig. 32) by Fränkl (1955) and Cowie (1971). Clearly, comments made here are of a preliminary nature, and final nomenclative revision of the sequence must await re-examination of the various localities visited by Adams \& Cowie and by Fränkl. As a foreword to any discussion it must be stressed that the original field investigations made by these three authors were necessarily of a brief reconnaissance nature.

Adams \& Cowie (1953) gave the name Centrum Limestone to a sequence of carbonates which they considered to be approximately $2-3 \mathrm{~km}$ thick and to range in age from the late Early Ordovician to the Silurian. Sections were measured from near the head of Danmark Fjord to Centrum Sø. Fränkl (1955) gave the name Danmarks Fjord Dolomite to 10-30 m of dolomite underneath the Centrum Limestone but above the Kap Holbæk Sandstone. The unit is indicated as present in the Danmark Fjord sequence of Adams \& Cowie, where it is apparently considered to be equivalent to the lowest beds of the Centrum Limestone. Fränkl also introduced the names Drømmebjerg Limestone and Profilfjeldet Shales for strata immediately north of Centrum Sø which occurred above the Centrum Limestone. The Drømmebjerg Limestone, $150-200 \mathrm{~m}$ of reef-like limestones yielded fossils of Middle Silurian age. The overlying $300-400 \mathrm{~m}$ thick Profilfjeldet Shales consisted of shales which became more sandy upward; graptolites indicated a Middle Silurian age.

Cowie (1971, p. 368) gave the name Amdrup Formation "for the lower part of the thick Centrum Limestone", confirming that this $240 \mathrm{~m}$ formation and the underlying Danmark(s) Fjord Formation are the "basal strata of the previously undivided Centrum Limestone".

Scrutton (1975), following his description of corals and stromatoporoids collected by Adams \& Cowie, reviewed the history and redescribed the stratigraphy of the Centrum Limestone. He recognised the Danmarks Fjord Formation as the basal $10 \mathrm{~m}$ of the original Centrum Limestone, resting on the Kap Holbæk Formation (referred to as the Cape Holbæk Formation). The overlying Amdrup Formation was restricted from the $240 \mathrm{~m}$ of limestones at localities 1-3 of Adams \& Cowie, as described by Cowie (1971), to the $190 \mathrm{~m}$ of strata present at localities 1 and 2 , on essentially faunal grounds. The lower $190 \mathrm{~m}$ were considered to be of late Early Ordovician age while the upper $50 \mathrm{~m}$ yielded late Middle Ordovician fossils. No Chazyan (early Middle Ordovician) fossils were recorded. Consequently, the upper $50 \mathrm{~m}$ of the original Amdrup Formation were transferred to a new formation, informally referred to as the 'Opikina Limestone'. The overlying Centrum Formation was attributed a thickness of $2050 \mathrm{~m}$, although Adams \& Cowie (1953, p. 14) could only originally estimate the thickness of the entire carbonate sequence to "probably between 2000 and 3000 metres, ... for convenience ... circa 2500 metres." Scrutton considered this restricted Centrum Formation to be entirely of Ordovician age, on the basis of coral identifications, and noted that the previous determinations of these corals as largely Silurian by Adams \& Cowie were seriously incorrect.

Scrutton $(1975$, p. 8) commented that the top $200 \mathrm{~m}$ of the Centrum Limestone sensu Adams \& Cowie (1953) had been separated off as the Drømmebjerg Formation, an act 


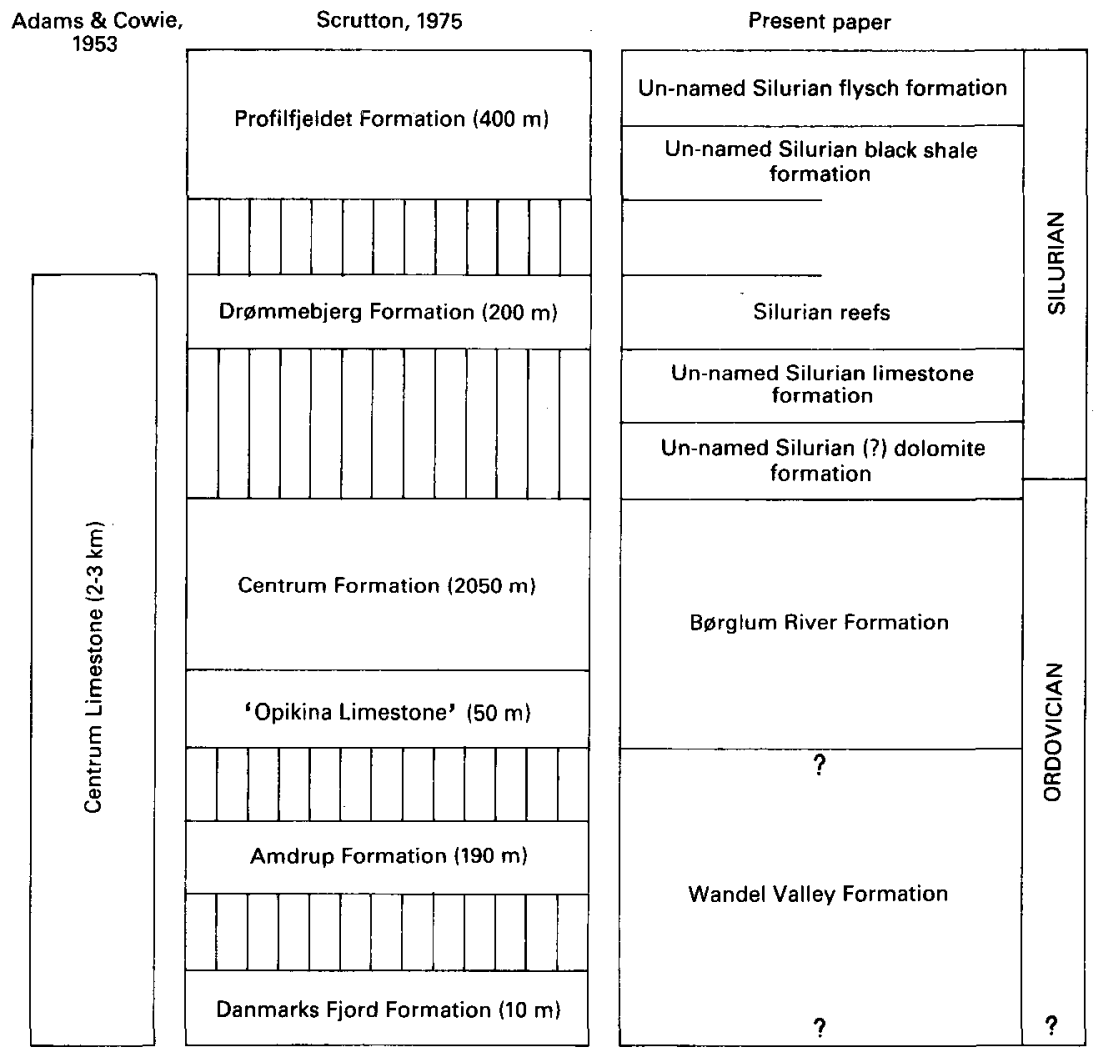

Fig. 32. Stratigraphic schemes for the Lower Palaeozoic of Kronprins Christian Land.

which he attributed to Fränkl (1955, p. 22) and Cowie (1961, p. 164). The information supplied by the cited sources is unfortunately ambiguous. However, it may be inferred from the geological map given by Fränkl $(1955$, pl. 1) that the highest locality (locality 9) within the Centrum Limestone sensu Adams \& Cowie does lie within the Drømmebjerg Formation. Hence, the original Centrum Limestone did include the Drømmebjerg Formation.

The nett result of the various modifications in the nomenclature of the Centrum Limestone during the period 1953 - 1975 is summarised in fig. 32. It is clear that the Centrum Formation is now used in a much more restricted sense than the original Centrum Limestone, although its definition is hardly more precise. The several subsequently named formations contribute some apparent precision, although these units are also inadequately defined or described. In addition, the 1979 field work in northern Kronprins Christian Land has revealed two potentially major hindrances to the continued employment of the Centrum Limestone based stratigraphy. Firstly, the un-named Silurian(?) dolomite and Silurian limestone formations of Christie \& Peel (1977) are of widespread occurrence in northern Kronprins Christian Land (fig. 32) but are not recognisable in Scrutton's summary. Secondly, the frequent repetition of carbonate units by thrusting, evident in northern Kronprins Christian Land (fig. 33), was seemingly not recognised in southern Kronprins Christian 
Land by Adams \& Cowie (1953), although Haller $(1970,1971)$ has recorded thrusts near localities visited by Adams \& Cowie. The considerable thickness still attributed to the Centrum Formation in Scrutton's summary (fig. 32) might itself be evidence of the influence of both these factors.

No adequate solution to the stratigraphic nomenclature problems is currently available. However, there is little to be gained from employing the terms included in Scrutton's summary until these have been re-evaluated in the field. In consequence, names given to the Peary Land Ordovician-Silurian carbonate sequence by Troelsen (1949) and Christie \& Peel (1977) are used in this context, since the successions in Peary Land and northern Kronprins Christian Land are essentially identical. It is recognised, however, that some of the terms used in Scrutton's summary may eventually be maintained. A correlation between Scrutton's summary and the Peary Land scheme is given in fig. 32, although this makes the probably untenable assumption that the Centrum Formation is exactly equivalent to the Børglum River Formation and undisturbed by tectonism.

\section{Wandel Valley Formation}

This formation outcrops only in the extreme north-west of the field area where an approximately $200 \mathrm{~m}$ thick sequence is overlain by the Børglum River Formation. Ceratopea from near the base of the section indicates a late Early Ordovician age, as in Peary Land, but the formation probably includes all or part of the Chazy (early Middle Ordovician) also. The base of the Wandel Valley Formation was not seen in Kronprins Christian Land during 1979 and hence its relationship to the Danmarks Fjord Formation cannot be assessed. In northern Valdemar Glückstadt Land (fig. 30, locality A; fig. 31), the Wandel Valley Formation lies directly on the Kap Holbæk Formation, having overstepped the Brønlund Fjord and Tavsens Iskappe Groups of Peary Land (Peel, 1979). The Danmarks Fjord Formation may thus just be equivalent to the basal beds of the Wandel Valley Formation, although possible correlations with the Portfjeld Formation (see discussion in O'Connor, 1979 and Peel, 1979) and part of the Brønlund Fjord Group, as suggested by Cowie (1971), cannot yet be fully discounted.

\section{Børglum River Formation}

Although present near Danmark Fjord, this formation was only examined on the ground at locality $\mathrm{C}$ in fig. 33. Here, more than $300 \mathrm{~m}$ of typical Børglum River Formation (Troelsen, 1949; Christie \& Peel, 1977) dip east-south-east at about $35^{\circ}$ and are overlain without obvious structural complications by the un-named Silurian(?) dolomite formation. Abundant fossils, compressed slightly parallel to the dip, indicate that the formation is relatively completely represented. Gonioceras from near the base indicates a late Middle Ordovician age and suggests that the 'Opikina Limestone' of Scrutton (1975) may just be the lower part of this formation. Abundant late Ordovician corals from higher in the formation are comparable to the faunas described by Scrutton (1975) from the Centrum Formation. Ignoring the anomalous thickness, this latter formation and the underlying 'Opikina Limestone' can probably be safely equated with the Børglum River Formation, although additional field work is required to settle this point. 


\section{Un-named Silurian(?) dolomite formation}

This unit is distinctive in the field on account of its rapid lithological alternation of pale grey dolomites and darker grey dolomitic limestones. These form a striking contrast with the underlying dark brown weathering Børglum River Formation and the overlying yellowish brown un-named Silurian limestone formation. The formation is well exposed, on account of repetition by thrusting and reverse faulting. Fossils were collected from a number of horizons, especially near locality $\mathrm{C}$ in fig. 33, where the formation overlies the Børglum River Formation with apparently normal sedimentary contact. The lowest beds are of Ordovician age, although most of the formation can be referred to the Silurian.

A section through the formation was not measured, although it would appear that about $200 \mathrm{~m}$ of strata are present near Danmark Fjord. The un-named Silurian(?) dolomite formation cannot be recognised in previous descriptions of the Centrum Limestone.

\section{Un-named Silurian limestone formation}

This formation of rather massive, yellowish brown weathering limestones also outcrops over a large part of the field area. However, in view of tectonism and the rapid reconnaissance nature of the 1979 field work, no reliable estimate of the thickness was made, although several hundred metres of strata are present. At locality D (fig. 33), the upper surface is marked by stromatolitic (?) domes which may be tens of metres across and with a relief of up to $5 \mathrm{~m}$. Dark shales of the overlying un-named Silurian black shale formation follow conformably. Upper beds of the Silurian limestone formation are rich in the domed stromatoporoids and colonies of tabulate corals characteristic of member $E$ of the formation in Peary Land (Christie \& Peel, 1977). No strata in the description of the Centrum Limestone given by Adams \& Cowie (1953) can be assigned to this formation.

\section{Silurian reefs}

White or pale grey weathering carbonate mounds are apparently widespread in northern Kronprins Christian land, although in the accompanying map they are not distinguished from the underlying Silurian limestone formation (fig. 33). The mounds appear identical to the Silurian reefs described by Christie \& Peel (1977) from Peary Land both in lithology and size. They are also similarly rooted in the underlying Silurian limestone formation with the shale and flysch formations, described below, flanking them. Noteworthy examples within the map area (fig. 33) occur adjacent to the small ice cap south-west of locality $C$, and in the area between localities $\mathrm{E}$ and $\mathrm{F}$. A particularly large mound forms hill tops in the area north-west of locality $D$.

On the basis of Fränkl's (1955) description, and the faunas described by Lane (1972) and Scrutton (1975), it would appear that it is to carbonate mounds of this type that the name Drømmebjerg Formation has been applied.

\section{Un-named Silurian black shale formation}

This is well exposed near locality D (fig. 33), but elsewhere through the region exposures are small and generally occur where masses of originally subjacent Silurian limestone or 


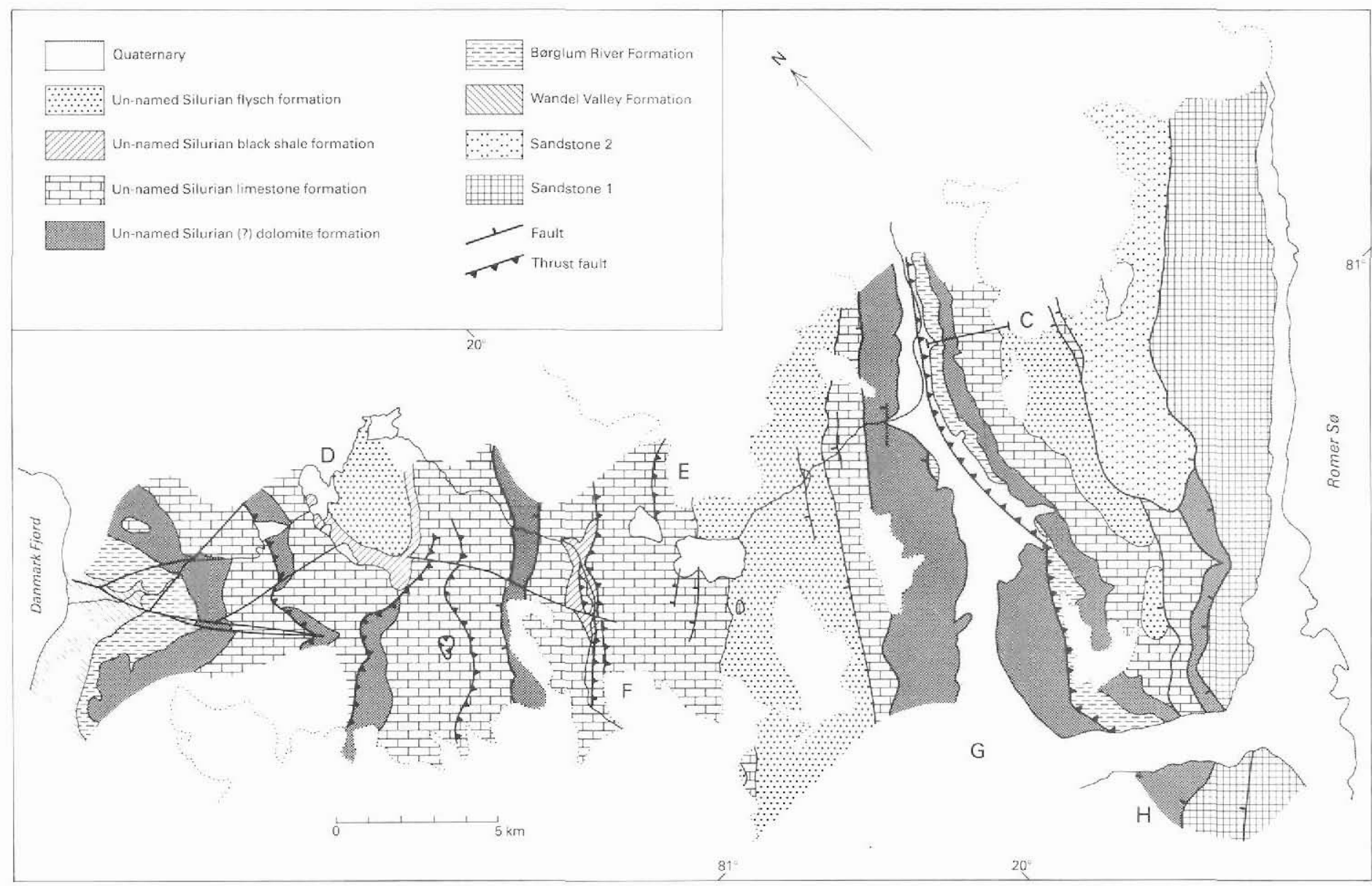

Fig. 33. Preliminary geological map along a transect from Danmark Fjord to Romer Sø. The individual geological units are formations described in the text. $\mathrm{C}-\mathrm{H}$ refer to localities discussed in the text. 
Silurian reefs have been faulted over the shale (e.g. at locality F). Middle Silurian graptolites have been collected from several localities. The shale was not observed in the eastern part of the area, at locality $\mathrm{C}$, but this absence could be due to thrusting. The black shales and the overlying un-named Silurian flysch formation can be readily identified with the Profilfjeldet Formation of Fränkl (1955).

\section{Un-named Silurian flysch formation}

The un-named Silurian flysch formation, known to be at least $1000 \mathrm{~m}$ thick in Peary Land (Christie \& Peel, 1977), is exposed in three principal areas. At locality D, shales of the Silurian black shale formation are succeeded without apparent structural complication by, very approximately, $100 \mathrm{~m}$ of flysch. In the belt of exposure south of locality E, strongly folded and faulted flysch overlies Silurian carbonates and shale along at least partially tectonised contacts. At locality $\mathrm{C}$, apparently undisturbed flysch lies in possibly normal sedimentary contact with a carbonate mound.

Flysch lithologies in northern Kronprins Christian Land are generally similar to those seen in Peary Land by Christie \& Peel (1977). However, at locality C beds of conglomerate, a few metres thick, contain clasts of limestones readily identifiable with Ordovician and Silurian units in the same area, mixed with sandstones and metamorphic and crystalline rock types.

\section{Proterozoic sandstones}

Two units, referred to as sandstones 1 and 2, are considered to be Proterozoic or possibly in part earliest Cambrian, on the basis of Fränkl's (1954, 1955) descriptions and maps. Sandstone 1 was not examined on the ground but can with some certainty be equated with the Rivieradal Sandstones which Fränkl (1954) described as alternating light grey sandstones and dark shales. From the air, the strikingly persistent bedding (Haller, 1970, fig. 14) gives the impression of a turbidite sequence but this is not substantiated. The unit overrides sandstone 2 and Silurian strata along a dislocation which dips steeply to the south-east.

The area in fig. 33 mapped as sandstone 2 almost certainly includes a variety of rock units and lithologies but these could not be delimited in the time available. The rather generalised map of Fränkl (1954, plate 1) indicated the presence of the Ulvebjerg Sandstones and Tillites and the Campanuladal Limestone. However, the only lithology examined on the ground, a hard white quartzite, cannot be readily attributed to any of these units as described by Fränkl.

\section{Structure}

As noted above, Haller (1971, fig. 88) divided the map area (fig. 33) into two structural zones, a western foreland zone and an eastern zone of nappes. The boundary between the two was drawn at the prominent north-east to south-west Quaternary filled valley at locality G. The foreland zone was considered to be principally occupied by weakly folded and thrusted Centrum Limestone, although the folds increased in tightness in the area north-east of Romer Sø. The zone of nappes was considered by Haller to include pre-Centrum Limestone strata, with no Centrum Limestone recognised at that time. 
Clearly, the present restricted cross-section permits little comment concerning the regional applicability of Haller's zonation and, for the purposes of the present discussion, the mapped area is subdivided into three. The first of these subareas stretches from Danmark Fjord in the north-west to the belt of Silurian flysch outcropping at locality E and consists primarily of the Silurian(?) dolomite and Silurian limestone formations repeated by thrusts and higher angle reversed faults. Folding is minimal but to the north-east, outside the map (fig. 33), it increases in intensity until tightly folded carbonates occur in the most easterly outcrops. The shallow syncline with the Silurian black shale and Silurian flysch formations at locality D may be overthrust along its eastern margin. There is generally little deformation or brecciation associated with fault planes. Stratal dips vary between 5 and 20 degrees approximately to the south-east. A series of small normal faults trends approximately perpendicular to the strike.

The second subarea encompasses the belt of Silurian flysch south of locality E and the carbonates immediately to the south-east. The subarea is bounded by the thrust occupying the prominent Quaternary filled valley running north-east to south-west at locality G. Exposure is generally poor in this area but the general pattern seems to be of closely spaced reverse faults, steeply dipping carbonates and rather tightly folded flysch.

The third subarea lies between the thrust north-east of $G$ in fig. 33 and Romer Sø. The uniform 35 degrees dip of the conformable Palaeozoic section at locality $C$ contrasts strongly with the much disturbed sequence across the valley to the west. The sequence is evidently a thrust sheet but the structural cross-section at locality $\mathrm{H}$ (fig. 34) suggests that horizontal displacement is inconsiderable. To the south-east of locality C, several steeply inclined reverse faults repeat Silurian deposits before supposed Proterozoic sandstones are faulted over the Lower Palaeozoic, again along a steeply dipping dislocation. Sandstone 1 at locality $\mathrm{H}$ is folded into a syncline overturned to the north-west.

According to Haller (1971) all subarea three forms the western margin of an allochthonous zone of nappes, gliding off the rising Caledonides and with a root zone lying somewhere offshore, more than $100 \mathrm{~km}$ east of Romer Sø. There seems little reason to assign the Børglum River Formation to Silurian flysch sequence at locality $\mathrm{C}$ to such a far travelled sequence, particularly since the evidence from locality $\mathrm{H}$ suggests inconsiderable displacement along the thrust forming the north-west margin to the subarea. Presumably, therefore, any plane of gliding should lie above this level, namely to the south-east of the Lower Palaeozoic sequence. The high angle dislocation between the Proterozoic sandstones and the Lower Palaeozoic is clearly substantial, perhaps representing 2 or $3 \mathrm{~km}$ of stratigraphic thickness. However, the limited field observations made during 1979 supplied little evidence for the large scale horizontal displacement invoked by Haller, and evaluation of the gliding nappe hypothesis must await the more widespread field work planned for 1980.

\section{References}

Adams, P. J. \& Cowie, J. W. 1953: A geological reconnaissance of the region around the inner part of Danmarks Fjord, Northeast Greenland. Meddr Grønland 111(7), 24 pp.

Christie, R. L. \& Peel, J. S. 1977: Cambrian - Silurian stratigraphy of Børglum Elv, Peary Land, eastern North Greenland. Rapp. Grønlands geol. Unders. 82, 48 pp.

Clemmensen, L. B. 1979: Notes on the palaeogeographical setting of the Eocambrian tillite-bearing sequence of southern Peary Land, North Greenland. Rapp. Grønlands geol. Unders. 88, 15-22. 


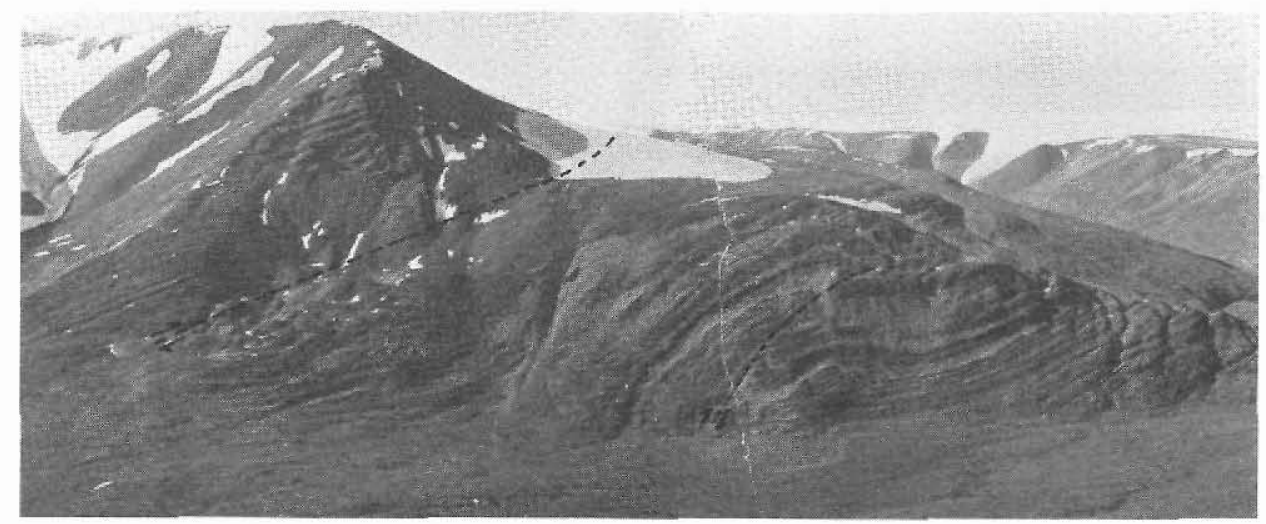

Fig. 34. Supposed Proterozoic sandstones (left) thrust over banded carbonates of the un-named Silurian (?) dolomite formation at locality $\mathrm{H}$, fig. 33. The view from the north of the south-east (left) to north-west (right) cliff face causes an apparent reduction in the angle of the dislocation. The small dislocation to the right, within the carbonates, is apparently equivalent to the large thrust separating structural subareas 2 and 3 , and indicates the minimal displacement along this plane.

Collinson, J. D. 1979: The Proterozoic sandstones between Heilprin Land and Mylius-Erichsen Land, eastern North Greenland. Rapp. Grønlands geol. Unders. 88, 5-10.

Cowie, J. W. 1961: The Lower Palaeozoic geology of Greenland. In Raasch, G. O. (edit.) Geology of the Arctic 1, 160-169. Toronto U. P.

Cowie, J. W. 1971: The Cambrian of the North American Arctic regions. In Holland, C. H. (edit.) Cambrian of the New World, 325-383. London: Interscience.

Dawes, P. R. 1976: Precambrian to Tertiary of northern Greenland. In Escher, A. \& Watt, W. S. (edit.) Geology of Greenland, 248-303. Copenhagen: Geol. Surv. Greenland.

Fränkl, E. 1954: Vorläuflige Mitteilung über die Geologie von Kronprins Christians Land (NE-Grönland). Meddr Grønland 116(2), $85 \mathrm{pp.}$

Fränkl, E. 1955: Weitere Beiträge zur Geologie von Kronprins Christians Land (NE-Grönland). Meddr Grønland 103(7), 35 pp.

Haller, J. 1970: Tectonic map of East Greenland (1:500,000). Meddr Grønland 171(5), 286 pp.

Haller, J. 1971: Geology of the East Greenland Caledonides. 413 pp. London: Interscience.

Håkansson, E. 1979: Carboniferous to Tertiary development of the Wandel Sea Basin, eastern North Greenland. Rapp. Grønlands geol. Unders. 88, 73-84.

Lane, P. D. 1972: New trilobites from the Silurian of north-east Greenland. Palaeontology 15, 336-364.

Lane, P. D. \& Thomas, A. T. 1979: Silurian Carbonate mounds in Peary Land, North Greenland. Rapp. Gronlands geol. Unders. 88, 51-54.

O'Connor, B. 1979: The Portfjeld Formation (? early Cambrian) of eastern North Greenland. Rapp. Grønlands geol. Unders. 88, 23-28.

Peel, J. S. 1979: Cambrian - Middle Ordovician stratigraphy of the Adams Gletscher region, south-west Peary Land, North Greenland. Rapp. Gronlands geol. Unders. 88, 29-39.

Peel, J. S. 1980: Early Cambrian microfossils from the Portfjeld Formation, Peary Land, eastern North Greenland. Rapp. Grønlands geol. Unders. 100, 15-18.

Scrutton, C. T. 1975: Corals and stromatoporoids from the Ordovician and Silurian of Kronprins Christian Land, Northeast Greenland. Meddr Grønland 171(4), 43 pp.

Troelsen, J. C. 1949: Contributions to the geology of the area round Jørgen Brønlunds Fjord, Peary Land, North Greenland. Meddr Grønland 149(2), 29 pp. 